\title{
Factors Associated with Bullying Behavior in Islamic Private Schools, Pattani Province, Southern Thailand
}

\author{
Kasetchai Laeheem ${ }^{1}$ \\ ${ }^{1}$ Research Center for Asia Pacific Development Studies, Faculty of Liberal Arts, Prince of Songkla University, \\ Hatyai, Thailand \\ Correspondence: Kasetchai Laeheem, Research Center for Asia Pacific Development Studies, Faculty of Liberal \\ Arts, Prince of Songkla University, Hatyai, Songkhla, Thailand, 90110. E-mail: Lkasetchai@yahoo.com
}

Received: December 22, 2012 Accepted: January 11, 2013 Online Published: February 28, 2013

doi:10.5539/ass.v9n3p55

URL: http://dx.doi.org/10.5539/ass.v9n3p55

\begin{abstract}
The purpose of this research was to investigate the associations between students' bullying behaviors in Islamic private schools, Pattani province and classroom management factors (democracy, authoritarian, and permissive classroom management), family upbringing factors (strict, permissive, and democracy upbringing), environment violence factors (influence of peers violence, community violence, and parents violence), and to identify risk factors for bullying behaviors. A cross-sectional survey was conducted among 1,500 students were interviewed to collect relevant data by using a screening inventory for students at risk of exposure to bullying behavior in Islamic private schools (Laeheem \& Sungkharat, 2012). Pearson Product-moment correlation test was used to analyze the associations between bullying outcome and various determinants linked to classroom management factors, family upbringing factors, and environment violence factors. Multiple linear regression analysis was used to identify risk factors for bullying. The study indicated that there were significant associations between bullying behavior and authoritarian classroom management, strict upbringing, influence of peers violence, and influence of parents violence. The influence of parents violence was clearly the most strongly associated predictors in explaining the students bullying behavior (Beta value $=2.26$ ). The strict upbringing, authoritarian classroom management, and influence of peers violence were also made some contribution in explaining the variance in the students bullying behavior (Beta value $=1.93,0.23$, and -3.27 ), respectively.
\end{abstract}

Keywords: bullying behavior, Islamic private schools, classroom management factors, family upbringing factors, and environment violence factors

\section{Introduction}

Bullying is a common behavioral problem occurring in Islamic private schools, is considered a common problem in schools and is well-known to among all parties concerned such as among students themselves, parents, teachers and educators. It is still a worrying problem which affects students' quality of life, inflicting psychological, emotional, and physical damage and occurs throughout the world beyond (Kochenderfer \& Ladd, 1996; Laeheem, Kuning, McNeil, \& Besag, 2008). School bullying can be defined as any negative actions repeatedly inflicted by a stronger student or student gang toward another student (Farrington, 1993; Olweus, 1999). This negative action must be deliberate and carried out with the intent of causing harm to the victim (Farrington, 1993). Bullying might be classified in a variety of ways including physical assaults and psychological or emotional or verbal harassment (Laeheem, Kuning, \& McNeil, 2009). Physical bullying is an action oriented and an intended to intimidate or physically hurt the victim through pinching, pushing, kicking, and hitting, while verbal bullying is using words to humiliate or hurt someone's feelings through teasing, name-calling, insulting, or threatening behavior (Beale, 2001; Woods \& Wolke, 2004; Gini, 2004).

The major reasons that children bully others are to enjoy exercising power and status over their victims, boredom, jealousy, attention seeking, showing off, anger, revenge, and self-protection (Besag, 1989; Besag, 2006). In this way, bullying eases the way for children to be drawn into a path of delinquency, vandalism and criminality (Farrington, 1993; Junger, 1996). The targets or victims of school bullying are at risk of a variety of negative outcomes. They are more likely than non-victimized children to become anxious, insecure, lonely, depressed, to be rejected by their peers, drop out of school, feud, or decide to protect themselves by carrying guns/weapons to school (Boulton \& Underwood, 1992; Craig, 1998). 
There are many causes of bullying, such as domestic violence or physical abuse between parents (Singer, Miller, Guo, Slovak, \& Frierson, 1998; Baldry, 2003). Witnessing parental physical abuse was clearly the most strongly associated determinant linked to bullying and aggressive behaviors than those who had never witnessed parental physical abuse (Laeheem \& Baka, 2011). Parental modelling of aggression and violence promotes the development of a child's negative behavior; the child might copy the parent's physical actions and might then become a bully to gain success in their own social interactions. Exposure to parental family violence has been found to be related to negative behavior of students; those witnessing it are likely to display increased violent behavior (Singer, Miller, Guo, Slovak, \& Frierson, 1998; Rossman, Hughes, \& Rosenburg, 2000). Exposure to parental family violence has been found to be related to negative behaviors of students; the students who had witnessed parental physical abuse were more likely to bully others and violent behaviors, when compared to those who had not witnessed parental physical abuse (Laeheem \& Baka, 2009). The students living with parental physical abuse were found to be at increased risk of experiencing violent behavior or bully other (Jaffe, Wolfe, \& Wilson, 1990; Pepler \& Sedighdeilami, 1998).

This study aims to investigate the associations between students' bullying behaviors and various determinants, and to identify risk factors for students' bullying behaviors in Pattani Islamic private schools including classroom management factors (democracy classroom management, authoritarian classroom management, and permissive classroom management), Family upbringing factors (strict upbringing, permissive upbringing, and democracy upbringing), environment violence factors (influence of peers violence, influence of community violence, and influence of parents violence). By identifying students who are likely to bully others; findings from this study should help in the development of prevention and intervention policies in the primary schools and assist educational authorities to introduce better strategies for reducing and preventing this problem, and may give the necessary information to teachers and administrators responsible for improving existing awareness programs, as well as continuing to educate our children in the safest and best learning environment possible.

\section{Methods}

\subsection{Participants}

The participants of the study consisted of 1,500 students which were drawn from fifteen schools; all of Islamic private schools in Pattani Province, Southern Thailand, and were selected 100 students per school. The age of the participants was between 6 to 13 years (Mean $=9.33$, S.D. $=2.09$ ). About $52.1 \%$ of the participants were females and $47.9 \%$ were males.

\subsection{Data Collection}

This study used a cross-sectional study design involving interviews and surveys of Islamic private schools students in a sample selected from the target population studied. Verbal consent to participate in the study was obtained from students after assurance of confidentiality was given to individuals and group administered. The collection assistants were teachers in target schools, who volunteered to participate. These teachers were trained in the interviewing techniques and the details of the questionnaire. They were asked to take care not to rush through the questionnaire and also to record responses accurately.

The teachers interviewed students in the classroom after permission was granted by the school principal. Each interviewed individual ages 6-8 years olds students (Grades 1-3 students); interviewed lasted approximately 25-35 minutes. Group administered (narrated) surveys of ages 9-12 years olds students (Grades 4-6 students) took approximately 45-55 minutes.

\subsection{Measures}

Classroom management factors is a self-report questionnaire which scored on a five-point rating scale, ranging from Never (1), Once or Twice (2), Sometimes (3), Regularly (4), and Very often (5). This questionnaire contains three subscales which include: democracy classroom management with 5 items, authoritarian classroom management with 5 items, and permissive classroom management with 5 items. The classroom management factors scale, was found to have acceptable internal consistency (Cronbach alpha $=.76$ ).

Family upbringing factors is a self-report questionnaire which scores on a five-point rating scale, ranging from Never (1), Once or Twice (2), Sometimes (3), Regularly (4), and Very often (5). The family upbringing factors questionnaires contain three subscales which include: strict upbringing with 5 items, permissive upbringing with 5 items, and democracy upbringing with 6 items. The internal consistency was .81 , which was found to have acceptable internal consistency.

Environment violence factors is a self-report questionnaire which comprised of 16 items with five-point rating scale, ranging from Never (1), Once or Twice (2), Sometimes (3), Regularly (4), and Very often (5). This 
questionnaire contains three subscales which include: influence of peers violence with 5 items, influence of community violence with 6 items, and influence of parents violence with 5 items. The alpha coefficient was found .82, which was found to be acceptable.

Bullying behavior is a self-report questionnaire by using a screening inventory for students at risk of exposure to bullying behavior in Islamic private schools (Laeheem \& Sungkharat, 2012) which measuring the tendency to bully others in the past year which consist of 28 items scored on a five-point rating scale, ranging from Never (1), Once or Twice (2), Sometimes (3), Regularly (4), and Very often (5). The Bullying behavior questionnaire contains two subscales which include: physical bully scale with 15 items (e. g., kicked, hit, bite, pushed, throwing something at, beat, and pinched), and verbal bully scale with 13 items (e.g., name-calling, insulting parents' occupation, insulting parents' name, insulting appearance, insulting economic status, insulting academic achievement, and insulting by stating a physical disability). The internal consistence of the Bullying behavior questionnaire was found to be acceptable (Cronbach alpha $=.86$ ).

\subsection{Data Analysis}

All the predictor factors of interest and the bullying outcome were continues variables. Descriptive statistics was used to describe the main variables of the study. Pearson Product-moment correlation was conducted to test the associations between students' bullying behaviors in Islamic private schools, Pattani province and classroom management factors (democracy, authoritarian, and permissive classroom management), family upbringing factors (strict, permissive, and democracy upbringing), environment violence factors (influence of peers violence, community violence, and parents violence). Multiple linear regression analysis was performed to investigate any independent associations between bullying outcome and various determinants linked to classroom management factors, family upbringing factors, and environment violence factors (to identify risk factors for bullying), and variables were eliminated from the model by stepwise method.

\section{Results}

\subsection{Descriptive Statistics of Bullying and Predictor Variables}

In this study, the mean score of bullying outcome and predictor variables was interpreted based on Best (1981) guideline which suggested mean 1.00-1.49 scored as lowest, 1.50-2.49 scored as low, 2.50-3.49 scored as moderate, 3.50-4.49 scored as high, and 4.50-5.00 scored as highest. The result found that the level of the bullying behavior among of Islamic private school students in Pattani Province was at a moderate level (Mean= 3.09). The mean score of nine predictor variables, the democracy upbringing was at a high level (Mean=3.74), the permissive upbringing, the democracy classroom management, the strict upbringing, the permissive classroom management, the influence of peers violence, the influence of parents violence, and the influence of community violence were at moderate level (the mean score were 3.36, 3.35, 3.10, 3.09, 3.09, 3.08, and 2.83, respectively), and the authoritarian classroom management was at a low level (Mean=2.07), (see Table 1).

\subsection{Correlations between Bullying Outcome and Predictor Variables}

Pearson Product-moment correlation was conducted to test the relationship between bullying outcome and nine predictor variables and the interpretation of correlations is based on Cohen (1988) guideline which suggested $r=$. 10 to .29 as small, $r=.30$ to .49 as medium and $r=.50$ to 1.0 as large. The result of the analysis indicate that the bullying behavior were statistically significant associations with the authoritarian classroom management, permissive classroom management, strict upbringing, influence of peers violence, influence of community violence, and influence of parents violence $(\mathrm{P}=0.000)$. The bullying behavior were a positive and large correlation with strict upbringing $(\mathrm{r}=0.70,95 \% \mathrm{C} \mathrm{I}=0.68,0.73)$, with influence of parents violence $(\mathrm{r}=0.70$, $95 \% \mathrm{C} \mathrm{I}=0.67,0.72)$, with influence of peers violence $(\mathrm{r}=0.69,95 \% \mathrm{C} \mathrm{I}=0.66,0.71)$, and with authoritarian classroom management $(\mathrm{r}=0.65,95 \% \mathrm{C} \mathrm{I}=0.62,0.68)$. The bullying behavior was a positive and medium correlation with influence of community violence $(\mathrm{r}=0.42,95 \% \mathrm{C} \mathrm{I}=0.38,0.46)$, and was a positive and small correlation with permissive classroom management ( $\mathrm{r}=0.27,95 \% \mathrm{C} \mathrm{I}=0.23,0.32)$, (see Table 1).

\subsection{Multiple Linear Regression Analysis of Bullying Others}

Multiple linear regression analysis was performed to determine whether the relationship between bullying outcome and predictor variables. The results revealed that there were statistically significant associations between bullying behavior and authoritarian classroom management, strict upbringing, influence of peers violence, and influence of parents violence. The residual deviance of 0.37 on 1495 degrees of freedom $(\mathrm{p}=0.000)$ and the four predictor variables explain about $60.07 \%$ of the variance in bullying behavior.

As depicted in Table 2, the largest beta coefficient obtained was $2.26(95 \% \mathrm{C} \mathrm{I}=1.89,2.67)$ for influence of parents violence, this means that the influence of parents violence made the strongest unique contribution in 
explaining the students bullying behavior, when the variance explained by all the other predictor variables in the model was controlled for. It suggests that one standard deviation increase in influence of parents violence is followed by 2.26 standard deviation increase in bullying outcome. The Beta value for strict upbringing, authoritarian classroom management, and influence of peers violence were 1.93 (95\% C I= 1.55, 2.17), 0.23 $(95 \%$ C I $=0.16,0.20)$, and $-3.27(95 \% \mathrm{C} \mathrm{I}=-4.12,-3.02)$, respectively. This means that the three predictor variables also made some contribution in explaining the variance in the students bullying behavior.

Table 1. Correlations between outcome variable: bullying behavior and predictor variables

\begin{tabular}{|c|c|c|c|c|c|}
\hline \multirow[b]{2}{*}{ Variables } & \multirow[b]{2}{*}{$\begin{array}{l}\text { Mean } \\
\text { Score }\end{array}$} & \multirow[b]{2}{*}{ S.D. } & \multicolumn{3}{|c|}{ Correlation with bullying } \\
\hline & & & $\mathrm{r}$ & $\mathrm{p}$ value & $\begin{array}{l}95 \% \text { Confidence } \\
\text { interval }(\mathrm{CI})\end{array}$ \\
\hline Bullying behavior & 3.09 & 0.58 & & & \\
\hline Democratic classroom management & 3.35 & 0.46 & -0.03 & 0.233 & $-0.08,0.20$ \\
\hline Authoritarian classroom management & 2.07 & 0.87 & 0.65 & 0.000 & $0.62,0.68$ \\
\hline Permissive classroom management & 3.09 & 0.32 & 0.27 & 0.000 & $0.23,0.32$ \\
\hline Strict upbringing & 3.10 & 0.51 & 0.70 & 0.000 & $0.68,0.73$ \\
\hline Permissive upbringing & 3.36 & 0.33 & -0.02 & 0.344 & $-0.07,0.03$ \\
\hline Democratic upbringing & 3.74 & 0.32 & -0.01 & 0.984 & $-0.05,0.05$ \\
\hline The influence of peer violence & 3.09 & 0.50 & 0.69 & 0.000 & $0.66,0.71$ \\
\hline The influence of community violence & 2.83 & 0.90 & 0.42 & 0.000 & $0.38,0.46$ \\
\hline The influence of parental violence & 3.08 & 0.50 & 0.70 & 0.000 & $0.67,0.72$ \\
\hline
\end{tabular}

Table 2. Reduced linear regression model of association between predictor variables and the outcome variable: bullying behavior, final model

\begin{tabular}{lrrrc}
\hline \multicolumn{1}{c}{ Predictor Variables } & B & S.E. & p value & $95 \%$ CI \\
\hline Constant & 1.15 & 0.07 & 0.000 & $0.16,0.20$ \\
Authoritarian classroom management & 0.23 & 0.01 & 0.000 & $0.16,0.20$ \\
Strict upbringing & 1.93 & 0.16 & 0.000 & $1.55,2.17$ \\
The influence of peer violence & -3.72 & 0.29 & 0.000 & $-4.12,-3.02$ \\
The influence of parental violence & 2.26 & 0.20 & 0.000 & $1.89,2.67$ \\
\hline
\end{tabular}

Note: Multiple R-squared: 0.6007, Adjusted R-squared: 0.5996,

Residual standard error: 0.3662 on 1495 degrees of freedom

\section{Discussion and Conclusions}

In this study investigated the associations between students' bullying behavior in Islamic private schools, Pattani province and nine determinants variables linked to democracy classroom management, authoritarian classroom management, permissive classroom management, strict upbringing, permissive upbringing, democracy upbringing, influence of peers violence, influence of community violence, and influence of parents violence. Results indicate that the bullying outcome was statistically significant associations with four predictor variables, namely authoritarian classroom management, strict upbringing, influence of peers violence, and influence of parents violence, and the four predictor variables explain about $60.07 \%$ of the variance in bullying behavior. Influence of parents' violence was clearly the most strongly associated predictors in explaining the students bullying behavior. This means that the violence between parents has been found to be related to negative behaviors of students; the students who had high level of witnessed parental physical abuse were more likely to bully others than those who had low level of witnessed parental physical abuse. This is a negative impact indirectly on the students' behavior, that students might imitate the parent's violent behavior and might then become a bully to gain success in his or her daily life at theirs schools. This was consistent with the studies of 
Rossman, Hughes, and Rosenburg (2000), Herrera and McCloskey (2001), Baldry (2003), and Laeheem, Kuning, McNeil, and Besag (2008), and Laeheem, Kuning, and McNeil (2009) who all reported that parental modeling of violence promotes the development of a students' negative behavior and may also influence students viewers to transfer violent acts from parents to real-world situations and has a significant additional effect in predicting bullying others; the students might copy the parent's physical actions and might then become a bully to gain success in their own social interactions.

Students often use the same violent behavior tactics that they observe from their parents; they learn to act violent behavior and to bully other students when they model the behavior of violent acts. According to Larson (2003) and Baldry and Farrington (1998) who argued that the students living with domestic violence are at risk of increased emotional and behavioral problems, and were found to be at increased risk of experiencing emotional or physical abuse. The frequent conflict between parents can result in their students performing bullying behavior (Espelage \& Swearer, 2003). Students often copy the physical actions of parents and so through their life experiences learn to be bullying others. By personally observing others acting violently to achieve some goal the students might learn to act violently (Gerbner, Gross, \& Melody, 1982; Williams, 2007). This is consistent with the study of Bandura (1975) who found that most human behavior is learned observationally through copying: from observing others one forms an idea of how new behaviors are performed, and on later occasions this coded information serves as a guide for action. Siegel (1998) argued that the students learn to act violently when they model the behavior of violent acts by adults, especially family members. Allen and Santrock (1993) who noted that the students attend to what the parents are doing and saying in order to reproduce the model's behavior.

This study showed that bullying is a serious problem in behavior in Islamic private schools, Pattani province. Influence of parents' violence or witnessing parental physical abuse was the highest risk factors associated with students' bullying behavior. Findings from this study should help in the development of prevention and intervention policies in the Islamic private schools and assist educational authorities to introduce better strategies for reducing the problem. Parents are the most important persons in providing leadership and direction for the successful prevention and intervention of bullying. They should provide close attention and talk regularly with their children about their feelings and relationships with friends at school. They should work in partnership with the school to encourage positive behavior. Moreover, they must have patience, try to avoid using violence, and closely advise and control the cartoon program viewing of their children. School administrators and teachers are the next most important persons for preventing the prevalence of bullying in schools. The school environment should be safe, orderly, and bully-free. Teachers have to provide positive and mature role-modeling in techniques to students and teach them how to interact with one another. They should develop a program that teaches students about the dangers of bullying, develop school personnel in teaching bully-free practices and teach students about all forms of bullying: verbal, emotional, psychological, and physical, as well as teach students about disadvantages of cartoon violence viewing and physical abuse between parents.

\section{Acknowledgements}

We are grateful to the Thailand Research Fun (TRF) for support this project.

\section{References}

Allen, L., \& Santrock, J. (1993). The contexts of behavior psychology. WI: Madison Brown \& Benchmark Press.

Baldry, A. C. (2003). Bullying in schools and exposure to domestic violence. Child Abuse \& Neglect, 27(7), 713-732. http://dx.doi.org/10.1016/S0145-2134(03)00114-5

Baldry, A. C., \& Farrington, D. P. (1998). Parenting influences on bullying and victimization. Criminal and Legal Psychology, 3, 237-254. http://dx.doi.org/10.1111/j.2044-8333.1998.tb00364.x

Bandura, A. (1975). Social learning and personality development. NJ: Rinehart \& Winston.

Beale, A. V. (2001). Bully busters': Using drama to empower students to take a stand against bullying behavior. Professional School Counseling, 4, 300-305.

Besag, V. E. (1989). Bullies and victims in schools. Milton Keynes: Open University Press.

Besag, V. E. (2006). Bullying among girls: Friends or foes? School Psychology International, 27(5), 535-551. http://dx.doi.org/10.1177/0143034306073401

Best, J. W. (1981). Research in education (4th ed.). NJ: Prentice-Hall, Englewood Cliffs.

Boulton, M., \& Underwood, K. (1992). Bully/victim problems among middle school children. British Journal of Educational Psychology, 62, 73-87. http://dx.doi.org/10.1111/j.2044-8279.1992.tb01000.x 
Cohen, J. W. (1988). Statistical power analysis for the behavioral sciences (2nd ed.). NJ: Lawrence Erlbaum Associates, Hillside.

Craig, W. (1998). The relationship among bullying, victimization, depression, anxiety and aggression in elementary children. Personality and Individual Differences, 24, 123-130. http://dx.doi.org/10.1016/S0191-8869(97)00145-1

Espelage, D., \& Swearer, S. (2003). Research on school bullying and victimization: What have we learned and where do we go from here? School Psychology Review, 32, 365-373.

Farrington, D. (1993). Understanding and preventing bullying. In M. Tonry, \& N. Morris (Eds.), Crime and Justice. Chicago: University of Chicago Press.

Gerbner, G., Gross, L. P., \& Melody, W. H. (1982). Violence and aggression, television and behaviour. NJ: Ten Years of Scientific Progress and Implications for the Eighties.

Gini, G. (2008). Associations between bullying behaviour, psychosomatic complaints, emotional and behavioural problems. Journal of Paediatric and Child Health, 44, 492-497. http://dx.doi.org/10.1111/j.1440-1754.2007.01155.x

Herrera, V. M., \& McCloskey, L. A. (2001). Gender differences in the risk for delinquency among youth exposed to family violence. Child Abuse \& Neglect, 25, 1037-1051. http://dx.doi.org/10.1016/S0145-2134(01)00255-1

Jaffe, P. G., Wolfe, D. A., \& Wilson, S. K. (1990). Children of battered women. CA Sage: Newbury Park.

Junger, T. J. (1996). Youth and violence in Europe. Studies on Crime and Crime Prevention, 5(1), 31-58.

Kochenderfer, B. J., \& Ladd, G. W. (1996). Peer victimization: manifestations and relations to school adjustment in kindergarten. Journal of School Psychology, 34, 267-283. http://dx.doi.org/10.1016/0022-4405(96)00015-5

Laeheem, K., \& Baka, D. (2009). Risk factors related to youths' violence behaviors in the three southern border provinces of Thailand. Songklanakarin Journal of Social Sciences and Humanities, 15(6), 897-911.

Laeheem, K., \& Baka, D. (2011). The risk factors are related to Thai Muslim youth's aggressive behavior in the three southern border provinces of Thailand. NIDA Development Journal, 51(3), 59-90.

Laeheem, K., \& Sungkharat, U. (2012). Development of screening inventory for students at risk of exposure to bullying behavior in Islamic private schools, Songkhla province. Kasetsart Journal of Socail Sciences, 33(2), 175-187.

Laeheem, K., Kuning, M., \& McNeil, N. (2009). Bullying: Risk factors becoming 'Bullies'. Asian Social Science, 5(5), 50-57.

Laeheem, K., Kuning, M., McNeil, N., \& Besag, V. E. (2008). Bullying in Pattani primary schools in southern $\begin{array}{llll}\text { Thailand. Child: care health \& development, } 35(2), & \text { 178-183. }\end{array}$ http://dx.doi.org/10.1111/j.1365-2214.2008.00890.x

Larson, M. S. (2003). Gender, race, and aggression in television commercials that feature children. Sex Roles, 48, 67-75. http://dx.doi.org/10.1023/A:1022396729398

Olweus, D. (1999). The nature of school bullying: A cross-national perspective. London: Routledge.

Pepler, D., \& Sedighdeilami, F. (1998). Aggressive girls in Canada. Ottawa: Applied Research Branch, Strategic Policy, Human Resources Development Canada.

Rossman, B. R., Hughes, H. M., \& Rosenburg, M. S. (2000). Children and interparental violence: The impact of exposure. Philadelphia PA: Brunner/Mazel.

Siegel, L. (1998). Criminology: Theories, patterns and typologies (6th ed.). Minn: West Publishing Company, St. Paul.

Singer, M. I., Miller, D. B., Guo, S., Slovak, K., \& Frierson, T. (1998). The mental health consequences of children's exposure to violence. Cleveland, $\mathrm{OH}$ : Mandel School of Applied Social Services, Case Western Reserve University.

Williams, G. (2007). Gabriel tarde and the imitation of deviance. Retrieved September 21, 2007, from http://www.criminology.fsu.edu/crimtheory/tarde.htm

Woods, S., \& Wolke, D. (2004). Direct and relational bullying among primary school children and academic achievement. Journal of School Psychology, 42, 135-155. http://dx.doi.org/10.1016/j.jsp.2003.12.002 